\title{
Michał Paluch
}

Uniwersytet Kardynała Stefana Wyszyńskiego w Warszawie

E-MAIL: paluchkonto@gmail.com

\section{Egzystencjał personalny nauczyciela - nowe podejście w dydaktyce ogólnej}

\section{STRESZCZENIE}

$\mathrm{W}$ artykule przedstawiona jest propozycja wykorzystania podstawowego terminu antropologii filozoficznej, jakim jest Osoba (osobotwórczość), w celu wydostania się z ciążącej na polskiej dydaktyce ogólnej bezosobowej epistemologii marksistowsko-leninowskiej. Aby zabieg ten uczynić czytelnym, autor podjął się krytycznego spojrzenia na naukową twórczość Wincentego Okonia (1914-2011), uchodzącego za niepodważalny autorytet w dziejach polskiej powojennej dydaktyki. Krytyka ta odbywa się na tle wyłaniającej się istoty Człowieka, przedstawionej przez Karola Wojtyłę (1920-2005), w dziele znanym jako Osoba i czyn (1969). Artykuł obfituje tym samym w język filozoficzny i wynikające z niego neologizmy, dawno niestosowane w polskim dyskursie dydaktycznym. Do takich autorskich pojęć należy „egzystencjał personalny", akcentujący potrzebę wyodrębnienia nauczania jako sposobu Bycia od innych przejawów ludzkiej egzystencji. Na tej podstawie ukazane zostały profile egzystencjalne wykładowców akademickich, wyprowadzone teoretycznie z personalizmu. Wyróżniono trzy egzystencjały personalne, będące wykładnią poziomów uczestnictwa nauczyciela we własnym wykładzie: (1) dydaktyczny (gr. didáskō, nauczam); (2) heurystyczny (gr. heuriskō, odnajduję, poszukując); (3) ginetyczny (gr. ginōskō, poznaję przez doznanie samego siebie). Na każdy z trzech egzystencjałów przypada określony typ tożsamości: (1) biernego wykonawcy czynności, (2) aktywnego twórcy dzieła oraz (3) przeżywającego relację z sobą samym i innymi sprawcę czynu nauczania. Artykuł ma charakter propedeutyczny. Pełny opis wybranych cech i wskaźników każdego z profili oraz ich pogłębione założenia teoretyczne i metodologiczne stanowią główną treść rozprawy doktorskiej' i przygotowywanej na jej podstawie osobnej publikacji.

SŁowa KLUCzowe: przeżywanie, nauczanie, podmiotowość, uczestnictwo, Osoba, marksizm, personalizm

1 Michał Paluch, praca doktorska pt. Dwoistość relacji dydaktycznej nauczyciel-dorosły uczeń, opracowana pod kierunkiem Prof. Bogusława Śliwerskiego. (Rozprawa obroniona została w Akademii Pedagogiki Specjalnej im. Marii Grzegorzewskiej, w Warszawie, w czerwcu 2020). 


\section{Wprowadzenie - alternatywa wobec materialistycznej spuścizny Wincentego Okonia}

Badanie profilu egzystencjalnego osoby, zwanego tu egzystencjałem personalnym, otwiera perspektywę analizowania nasilenia przeżycia przez nauczyciela, tego, co faktycznie o nim stanowi, w momencie nawiązania kontaktu z przedmiotem nauczania i innymi podmiotami (uczniami, studentami). W najbardziej ogólnym ujęciu jest to więc pytanie o to, czy mój sposób bycia nauczycielem jest w istocie byciem: czymś, jakimś czy kimś? Koncepcja egzystencjałów personalnych pomaga uświadomić sobie istnienie poziomów uczestnictwa we własnym wykładzie od uprzedmiotowionego sposobu bycia po bytowanie podmiotowo-osobowe.

Koncepcja ta uświadamia przy tym, że zobrazowane uczestnictwo w nauczaniu nie rozciąga się jedynie w wymiarze horyzontalnym - poznawczym. Sięga również profilu wertykalnego - związanego $\mathrm{z}$ doznawaniem owego poznania nie tylko w sferze norm estetycznych i logicznych - dotyczących nauczanego przedmiotu, ale przede wszystkim etycznych, związanych z doznaniem własnej podmiotowości, jak i podmiotowości swojego ucznia. Uzasadnieniem etycznej natury doznań poznawczych jest fakt, że dotyczą one doświadczenia wartości dobra wspólnego, wolności myślenia, a tym samym wartości prawdy o człowieku nauczającym i uczącym się. Czy kiedy staję przed uczniem, to moje „ja” jest faktycznie „mną"? Co to znaczy być „kimś” dla ucznia? Czy jestem dla ucznia świadkiem prawdy, czy tylko narzędziem komunikacji? Czy spełniam się w nauczaniu, czy odczuwam pustkę? Takie pytania stawia przed sobą badacz egzystencjałów personalnych, zainteresowany zarówno tym, dlaczego i jak nauczyciel działa, jak i tym, co wówczas w nim i z nim się dzieje ${ }^{2}$ - jak przeżywa współdziałanie i współdzianie się z uczniem.

$\mathrm{W}$ takim podejściu zasadza się główna różnica i przewaga personalizmu nad materializmem, który przedmiot przeżycia widział jedynie w materii zewnętrznej wobec człowieka, a nie w jego compositum świadomościowym i duchowym. Jeśli czytamy u Wincentego Okonia o przeżyciowym aspekcie nauczania i uczenia się, to podkreślić należy, że miał on na myśli przeżywanie poznawcze świata przyrody, społeczeństwa i nauki oraz prawideł nimi rządzących (Okoń, 1967, 1987; Zaczyński, 1984, 1990)³. Jakkolwiek postulował

2 Adagium: „Kiedy działam, coś wówczas ze mną i we mnie się dzieje” należy do podstawowego założenia antropologii filozoficznej Karola Wojtyły, podkreślanej wielokrotnie w jego dziele pt. Osoba i czyn (Wojtyła, 1969).

3 Zwracam uwagę, że teorie Wincentego Okonia, znane przede wszystkim pod postacią kształcenia wielostronnego oraz materializmu funkcjonalnego, są cytowane do dnia dzisiejszego w wielu podręcznikach, słownikach i publikacjach metodycznych, w tym - co 
stosowanie „metod eksponujących” wartości, to miał na uwadze wywołanie stosunku emocjonalnego ucznia do treści nauczania i przekonań społecznych (światopoglądowych), całkowicie pomijając subiektywny świat wartości intrai interpersonalnych.

Kolejnym argumentem przemawiającym za wyższością personalizmu nad materializmem jest dostrzeganie współzależności między sposobem bytowania (egzystowania) nauczyciela a aktywnością emotywną (duchową) jego uczniów i jego samego. Natomiast dydaktyk o orientacji materialistycznej nie widzi owej współzależności wewnątrz- i międzypodmiotowej. Podkreślał będzie - za Okoniem - związek przyczynowy jedynie między wyuczoną metodą, doborem treści i narzędziami działania nauczyciela a aktywnością poznawczą uczniów i jej efektywnością. W konsekwencji wielu nauczycieli w Polsce ogranicza własne pole działania i bytowania jedynie do celów, treści, metod, środków i kilku innych wskaźników materialistycznie zdefiniowanego „procesu kształcenia”. Jest to widoczne również tam, gdzie usilnemu stosowaniu popularnych dziś metod aktywizujących nie towarzyszy wewnętrzna aktywność osobotwórcza nauczyciela i jego ucznia. Podkreślam, że aktywność ta nie musi wiązać się z dużą atrakcyjnością retoryczną nauczyciela, jego kompetencjami liderskimi, dynamicznym moderowaniem rywalizujących zespołów czy stosowaniem inwazyjnych technik pobudzania funkcji poznawczych. Co zatem oznacza aktywność osobotwórcza?

W praktyce nauczania, jeśli już mielibyśmy wskazać na jakąś relację między bytem, aktywnością i metodą, jest ona odwrotna. To w sposobie naszego wewnętrznego bytowania, zręcznie określanego przez personalistów mianem actus internus, mieści się motywacja do ujawnienia samego siebie (actus externus) jako podmiotu podczas przedstawiania innym nauczanego przedmiotu. Stosując współczesny nam język, można powiedzieć, że wykładowca stanowi $\mathrm{z}$ jednej strony wykładnię wiedzy jako prawdy przedmiotowej, a z drugiej wykładnię samego siebie jako prawdy podmiotowej. W powojennej, jak i współczesnej dydaktyce ogólnej nie dostrzega się owych aktów i związanych z tym faktów. W konsekwencji nie zastanawiamy się nad tym, że zainteresowanie uczniów światem zewnętrznym współzależne jest $\mathrm{z}$ wewnętrznym światem nauczyciela.

szczególnie zastanawiające - w publikacji dotyczących nauczania katechetycznego (por. (Krasiński, 2001; Łuszczak, 2012).

4 Definicja „Procesu kształcenia”, zilustrowana graficznie w Encyklopedii Pedagogicznej $X X I$ wieku, to hybryda łącząca elementy procesu wzorowane bezpośrednio na dydaktyce radzieckiej z pomysłami W. Okonia i bezpodstawnie dodanym słowem "podmiot” już po roku 1989, tj. po zmianach ustrojowych (por. Ostrowska, 2005). 
Proponując alternatywny język wobec panującej w dydaktyce nomenklatury, uszlachetnionej sformułowaniami typu "traktowanie ucznia podmiotowo” czy też „aktywizowanie studentów”, wypada postawić pytanie równie ważne, jak zaniedbane: Jak wzbudzić u siebie i ucznia aktywność osobotwórczą? Innymi słowy, jak w biernym osobniku zainicjować aktywność na miarę osoby? Jest to pytanie o/i współprzeżywanie nauczania.

Aby odpowiedź była czytelna, należy przywrócić dydaktyce ogólnej terminy, pojęcia i zwroty zdefiniowane i przepracowane na gruncie antropologii filozoficznej, fenomenologii, hermeneutyki i dialogiki. Chcąc przy tym rozwijać teorię i praktykę kształcenia, nie możemy wstrzymywać się również przed autorskim tworzeniem konceptualizacji, neologizmów i prototerminów, czyniąc podłoże metodologiczne pod nowe badania empiryczne dla nas samych i kolejnych pokoleń badaczy. Koncepcja egzystencjałów personalnych stanowić może jeden $\mathrm{z}$ takich przykładów, wnosząc przy tym, do aktualnego dyskursu naukowego, zdecydowaną krytykę dydaktyki socjalistycznej i postsocjalistycznej autorstwa Wincentego Okonia i rzeszy jego naśladowców. Zadanie to jest naglące, ponieważ kolejne pokolenie nauczycieli szkolnych i akademickich, najczęściej nieświadomie, posługuje się nazewnictwem - a zatem i pewnym sposobem myślenia - ograniczającym możliwość wyrażania siebie adekwatnie do faktycznych przeżyć i doświadczeńs.

Ze względu na rozmiary artykułu krytyka dorobku dydaktyki powojennej i współczesnej jest tu jedynie zarysowana. Poza wprowadzeniem niektóre jej dookreślenia znajdują się w kolejnych akapitach. Kwestia podważenia autorytetu "patrona” rodzimej teorii nauczania i uczenia się może być słusznie odebrana jako kontrowersyjna, tym bardziej że przez całe dekady miał on (i ma nadal) nieograniczony wpływ na formację intelektualną wielu dydaktyków. Mając to na uwadze, dodaję w przypisie kilka źródeł, które stanowić mogą uzasadnienie i zachętę do dalszych krytycznych badań ${ }^{6}$. Przytoczę przy tym cytat Teresy Bauman, która już w 1993 roku uprzedzała o konsekwencjach braku podejmowanych zmian $\mathrm{w}$ obszarze rozumienia procesu kształcenia w Polsce:

5 Bolesnym tego dowodem jest teoretyczny i praktyczny paraliż metodologiczny tej dyscypliny i wynikająca z niego niezdolność kolejnych pokoleń nauczycieli i badaczy do wydostania się z ubogiej w formie i treści terminologii dydaktycznej.

6 Polecam artykuły własnego autorstwa pt. Wielostronne manipulacje twórcy wielostronnej teorii kształcenia (Paluch, 2016b) oraz Miary-godności pedagogów a wiary-godność dyscypliny. Granice (nie)przekraczalne (Paluch, 2016a). Rekomenduję przy tym podejmowanie pogłębionych badań literatury okresu przełomu lat 8o. i 9o. XX wieku, w których - w mojej ocenie - W. Okoń dokonał nieuprawnionego „miękkiego transferu” swoich treści do tworzącego się nowego dyskursu pedagogicznego. Skutki tego zabiegu odczuwalne są do dziś. 
Teoria zastygła w dogmacie niszczy samą siebie, bowiem po pewnym czasie staje się nieinspirująca i jałowa. [...] nieskora do samorefleksji, do zmiany, obligatoryjnie wprowadzana - jako obowiązujący sposób myślenia o rzeczywistości - powoduje narastanie stereotypów. Stereotypy w myśleniu zawsze prowadzą do uproszczeń, często opierają się na ukrytych, fałszywych założeniach, niekiedy są bronią w rękach polityków, ale prawdziwie niebezpieczne stają się wówczas, gdy posługują się nimi ludzie nauki, nazywając je "niepodważalnymi prawdami” (Bauman, 1993, s. 51).

\section{Stopniowe uwalnianie się od nomenklatury dydaktyki materialistycznej}

Jak nazywać fenomen (zjawisko) przeżyć nauczyciela i ucznia, egzystujących we wspólnym polu samodoświadczenia intra- i interpersonalnego? Po pierwsze, raz jeszcze podkreślę, że nie da się tego zrobić w oparciu o słownik dydaktyczny, jakim obecnie dysponujemy. Rekonstrukcja znaczeń podmiotowości osoby umożliwia współczesnym teoretykom nauczania i uczenia się otwarcie się nie tylko na bardziej adekwatny sposób wyrażania się o Człowieku ${ }^{8}$, ale na postawienie „zakazanych” wcześniej pytań. Dlatego problem badawczy, o kluczowym znaczeniu dla koncepcji egzystencjałów personalnych, wyrażam pytaniem: „Kto?”, zwracając uwagę, że przez ostatnie dekady skupiano się w dydaktyce ogólnej na odpowiadaniu jedynie na pytania: „Co?”, „Jak?” i „Po co?”. Pytania generowały niezwykle ograniczone w formie i treści odpowiedzi. Znamy je pod pojęciami typu: cele, treści, zasady, metody, techniki, środki, formy organizacyjne, oceny. Natomiast pytanie o uczestników nauczania w formie: „Kto?”, w pierwszej kolejności wymusza i wyznacza nową definicję podmiotu.

Podmiot, w koncepcji egzystencjałów personalnych, definiuję jako przedmiot własnego poznania (samopoznania) i doznań owego poznania (samodoświadczenia). W doznaniach tych bowiem mieszczą się te kategorie przeżyć, które odpowiadają określonemu poziomowi samostanowienia. Doznanie na poziomie bycia „czymś” odczuwalne jest jako apatia i pogłębiające się

7 Braki terminologiczne z zakresu podmiotowości człowieka są doskonale widoczne w słownikach pedagogicznych W. Okonia, których ostatnie (dziesiąte) wydanie miało miejsce raptem w 2007 roku. $\mathrm{Z}$ wyjątkowym przykładem niekompetencji autora w tym zakresie, a zarazem samozwańczą uzurpacją do definiowania podmiotowości nauczycieli spotykamy się w pracy pt. Rzecz o edukacji nauczycieli (Okoń, 1991).

8 Mam tu na myśli przywrócenie podstawowych kategorii ontologicznych, zapisywanych tradycyjnie w oryginalnej formie greckiej lub łacińskiej, oraz liczne pojęcia zakorzenione we współczesnej filozofii osoby i fenomenologii, jak: „samospełnienie się”, „samostanowienie”, „samodoświadczenie”, sprawczość, odpowiedzialność, czyn, „źródłowe doświadczanie siebie”, „zbliżenie świadomościowe”, doświadczenie dobra prawdy i prawdy o dobru. 
znużenie. Bycie „jakimś” wyzwala pasję tworzenia i współtworzenia wiedzy z innymi. Stawaniu się „kimś” towarzyszyć zaczyna doznawanie empatii i sympatii . Wyrazić to można lapidarnym stwierdzeniem: stanowi o mnie to, na jakim poziomie uczestniczę w człowieczeństwie własnym i mojego ucznia.

U samej swojej podstawy jest to więc pytanie o Człowieka partycypującego $^{10}$, a więc nie tylko dzielącego się wiedzą, co udzielającego się tą częścią siebie, która ów akt nauczania jakoś przeżywa. Z poziomu bycia „czymś” jest to ledwie odczuwalne doznanie aktywności zmysłowej i umysłowej na poziomie odzwierciedlania nauczanych treści. Z poziomu bycia ,jakimś” jest to przeżycie odkrycia intelektualnego, wynikającego $\mathrm{z}$ aktywności umysłowej zwanej refleksją. Na poziomie bycia „kimś” ujawnia się głębokie doznanie tego, co „nieredukowalne” w podmiocie osoby i co ująć można nie tyle w pojęciu „aktywności sumienia”, co w przeżyciu tej aktywności (por. Wojtyła, 2000, s. 439-441). Takie przeżycie jest już dalej „nieredukowalne”, stając się granicznym (źródłowym) doświadczeniem samego siebie.

Ponadto, zadając pytanie: „Kto?”, otrzymujemy odpowiedzi poddające się analizie w trzech - zaniedbanych przez materialistów - wymiarach, które streszczam w poniższej tabeli.

Tabela 1.

\begin{tabular}{|c|c|c|}
\hline \multicolumn{3}{|c|}{ Kto? - brakujące pytanie dydaktyki i funkcje jego zastosowania } \\
\hline $\begin{array}{c}\text { Funkcja } \\
\text { antropocentrująca }\end{array}$ & $\begin{array}{c}\text { Funkcja } \\
\text { eksperientalna }\end{array}$ & $\begin{array}{c}\text { Funkcja } \\
\text { transgresywna }\end{array}$ \\
\hline $\begin{array}{l}\text { Analizuje strukturę podmio- } \\
\text { tową człowieka od strony on- } \\
\text { tologiczno-epistemologicz- } \\
\text { no-aksjologicznej, stanowiąc } \\
\text { metafizyczną perspektywę } \\
\text { badawczą }\end{array}$ & $\begin{array}{l}\text { Rozpoznaje źródłowe } \\
\text { doznanie samego siebie, } \\
\text { jak i drugiej osoby jako } \\
\text { podmiotów egzystujących } \\
\text { we wspólnym polu samo- } \\
\text { doświadczenia, stanowiąc } \\
\text { fenomenologiczną perspek- } \\
\text { tywę badawczą }\end{array}$ & $\begin{array}{l}\text { Rekonstruuje wartość } \\
\text { człowieka po jego upad- } \\
\text { ku i przewiduje kolejne } \\
\text { mechanizmy degradujące } \\
\text { lub wzbogacające osobę, sta- } \\
\text { nowiąc metapedagogiczną } \\
\text { perspektywę badawczą }\end{array}$ \\
\hline
\end{tabular}

Źródło: opracowanie własne

Należy również zauważyć, że w kontekście nauczania, kiedy stawiamy sobie pytanie: „Kto?”, słyszymy odpowiedź nasuwającą się niejako spontanicznie.

9 Warto zwrócić uwagę, że rdzeniem wszystkich wymienionych doznań jest łacińskie słowo pati, wyrażające „dzianie się w człowieku i z człowiekiem” różnych przeżyć - „uczynnień”- na skutek jego świadomego „działania” (łac. agare) - czynu. (Za: Wojtyła, 20oo).

10 „Łacińskie participatio, będące źródłosłowem uczestnictwa, składa się ze słów: pars, oznaczającego «część» oraz rdzenia cip, pochodzącego od capere i tłumaczonego jako «wziąć». Nie odnosi się to jednak do brania części czegoś, ale do wzięcia udziału w czymś przez wolną i aktywną (czynną) część swojego «ja» zwaną «kimś»” (Paluch, 2020, s. 137). 
Zawiera się zarówno w zaimku osobowym „ja”, jak i w pewnym „drugim ja”, które przywykliśmy dotychczas traktować jako „ty”, znajdujące się w polu naszego oddziaływania. Jednak to nie pole oddziaływania jest tu określeniem adekwatnie oddającym czasoprzestrzeń nauczania, ale wspólne pole samodoświadczenia. Dlatego zanim przybliżę istotę „drugiego ja”, które na gruncie dydaktyki stanowi niezaprzeczalne novum, zwracam uwagę na istotną różnicę między oddziaływaniem na kogoś a współdziałaniem i współdzianiem się (z kimś). To dwa inne i niesprowadzalne do siebie doświadczenia, podobnie jak niesprowadzalna jest relacja nadawcy i odbiorcy do korelacji, a więc pogłębionej współzależności przeżycia „ja” i „drugiego ja”.

To ostatnie ma względem mojego „ja” taką samą potrzebę i nadzieję poznania, jaką i ja przejawiam przed nim. Nie ma niczego bardziej zasadnego w nauczaniu niż owo zbliżenie świadomościowe między nauczycielem i uczniem, któremu obydwaj zawdzięczają wpsółprzeżycie siebie samego, jak i siebie wzajemnie jako świadkowie prawdy. Na poziomie poznawczym przeżycie to przebiega inaczej u nauczyciela, a inaczej u ucznia, co wynika $\mathrm{z}$ różnic w aktualnym zasobie intelektualnym oraz indywidualnym stylu poznawczym. Natomiast na poziomie wolicjonalnym i duchowym przeżycie to jest na tyle do siebie zbliżone, na ile odróżnić można doznanie intelektualnego uniesienia u nauczyciela od doświadczenia momentu oświecenia przez jego ucznia. W każdym wypadku jest to swoiste i głębokie doświadczenie prawdy przedmiotowej, jak i podmiotowej. Nauczyciel w stanie uniesienia staje się świadkiem owej prawdy, zaś jego uczeń staje się jego świadkiem. Poznanie sprawcy aktu nauczania pozostaje w nas najczęściej na całe życie. Oto przejmująca siła wewnętrznego poruszenia osoby nauczającej i uczącej się oraz świadectw, jakie mogą im wówczas towarzyszyć.

Nie sposób w jednym artykule oddać możliwości rozwojowych dla dydaktyki, jakie wynikają z wciąż niedokonanej rekonstrukcji wielowiekowego dorobku największych myślicieli, w tym przedstawicieli personalizmu polskiego XX wieku. Równocześnie dostrzec należy liczne uzurpacje i redukcje poczynione nie tylko przez dydaktyków socjalistycznych, ale przedstawicieli dyscyplin pokrewnych, w tym szczególnie psychologii. W tym miejscu

Chodzi o każde „ja”, które - przez siebie samego - faktycznie przeżywa relację do „innego”. Wojtyła nazywa taki układ „ja” - drugi ja” (soi - autrui), w myśl tezy: „«Ty» jest drugim, innym ode mnie «ja»" (s. 397). Otwiera się wówczas „sytuacja poznawcza”, w której dochodzi do „zbliżenia świadomościowego" między dwoma skorelowanymi wewnętrznie i zewnętrznie podmiotami, zawsze jednak wychodzącymi od "przeżycia własnego ja”. W innym miejscu definiuje: „Drugie ja”, to pojęcie podkreślające pierwszoosobową perspektywę każdego innego „ty”, z którym moje „ja” wschodzi w interakcję (por. Wojtyła, 2000, s. 445-461). 
zaimek osobowy „Kto?” pełni jeszcze jedną funkcję - pyta o odpowiedzialność za wieloletnie (a wręcz międzypokoleniowe) upolitycznienie i zdegradowanie znaczenia Osoby w procesie kształcenia.

\section{Przegląd stanowisk teoretycznych - odpowiedzialni za monopol władzy i wiedzy}

Do najbardziej popularyzowanych dzieł okresu socjalizmu, jak i - co paradoksalne - czasów nam współczesnych, zaliczają się w pierwszej kolejności prace Wincentego Okonia, znajdujące swoje zwieńczenie w znanym i wielokrotnie wznawianym podręczniku pt. Wprowadzenie do dydaktyki ogólnej (wydawanym w latach 1987-2003) oraz w Słowniku pedagogicznym, aktualizowanym w latach 1975-2007. Analogiczną pozycją akademicką autorstwa Czesława Kupisiewicza jest podręcznik pt. Podstawy dydaktyki ogólnej (Kupisiewicz, 1973), wydawany do dziś i wielokrotnie modyfikowany. W tym gronie znajduje się najbardziej współczesna ich adaptacja autorstwa Franciszka Bereźnickiego pt. Dydaktyka szkolna dla kandydatów na nauczycieli (Bereźnicki, 2015).

Warto prześledzić najważniejsze teorie i podejścia zrodzone na gruncie innych dziedzin, na których dydaktycy socjalistyczni (i ich współcześni kontynuatorzy) oparli budowę schematu procesu kształcenia. Przede wszystkim są to transmisyjno-perswazyjne modele komunikacji ${ }^{12}$, tworzone w ramach rozwoju teorii systemów w połowie XX wieku (por. Jakobson, 1960; Lasswell, 1948; Shannon, 1948; Shannon i Weaver, 1949). Autorzy, często cytowani przez psychologów, podkreślali rolę nadawcy, kanału, komunikatu i odbiorcy. Podejście to odpowiadało również popularyzatorom prakseologii i cybernetyki w edukacji (zob. Poletajew, 1961; Graniewski i Kempista, 1963; Chałasiński, 1968; Mayer, 1969; Linhart, 1972; Dąbrowski, 1975; Tałyzina, 1980). Kierunki te bliskie były materialistycznej ideologii i epistemologii przez fakt podkreślania roli procesu jako działania usystematyzowanego, etapowego i kontrolowanego ${ }^{13}$. Materialiści w podobnym „duchu” utrzymywali atrakcyjność i ważność teorii rozwojowej Piageta, akcentując naukowe prawidła jej powstania (Aebli, 1982). Na gruncie polskiej psychologii podejście procesualne oddawała „teoria czynności” Tadeusza Tomaszewskiego (Tomaszew-

12 Przytoczone przeze mnie źródła anglosaskie nie zawsze występują w omawianej literaturze dydaktycznej. Należy jednak pamiętać, że autorzy socjalistyczni nie tylko podlegali presji nomenklatury radzieckiej, ale również wykazywali się odnajdywaniem wszelkich innych źródeł, które tylko potwierdzałyby mechanistyczny i proceduralny charakter poznania.

13 Warto zwrócić uwagę, że kierunki te, o wyraźnie mechanistycznym zabarwieniu, adaptowano zarówno w krajach ówczesnego Zachodu, jak też krajach Bloku Wschodniego. 
ski, 1969, 1970; por. Reykowski, 1958; Lewicki, 1960; Rubinsztejn, 1962) oraz „psychologiczna teoria decyzji” (Kozielecki, 1969, 1975). Teorie te miały i mają nadal bardzo duży wpływ na definiowanie procesu kształcenia w rodzimej literaturze, i do dziś nie zostały poddane krytycznej weryfikacji.

Tym samym zbiór dydaktycznych pojęć obfituje w sformułowania typu: elementy, składniki, czynniki, zasady, ogniwa, czynności, mechanizmy, procesy, układy, bodźce, reakcje, efekty, funkcje, struktury, stosunki, oceny, wzorce, system, temat, przedmiot, oraz dokumenty wieńczące tak pojmowaną całość, znane pod nazwami: konspekt lekcyjny, sylabus oraz ankieta (lub inne narzędzia pomiarowe) ewaluująca proces kształcenia. Mało kto kojarzy, że ten ostatni element, popularyzowany $\mathrm{z}$ dużym powodzeniem pod angielską nazwą feedback (informacja zwrotna, sprzężenie zwrotne), to również jeden z kluczowych terminów ukutych na gruncie teorii systemów i cybernetyki. Ostatecznie, jest to słownik bardzo ubogi, a zarazem szczególnie odporny na zmiany paradygmatyczne.

\section{Literatura nadziei - przełamanie doktryny przez Dorotę Klus-Stańską}

Pierwszy głos zdecydowanego sprzeciwu wobec powielanej przez dekady, bezkrytycznej recepcji twórczości W. Okonia wyraziła Dorota Klus-Stańska w roku $2010^{14}$, wraz z publikacją dzieła pt. Dydaktyka wobec chaosu pojęć i zdarzeń. Autorka podkreśliła zależność definiowania procesu kształcenia od „epistemologicznej leninowskiej teorii odbicia” (Klus-Stańska, 2010, s. 189), odczuwalną do dziś „inercyjność systemu dydaktycznego” (s. 257), "głęboką behawioryzację" koncepcji wszechstronnego kształcenia W. Okonia oraz jej opór przed „konstruktywistycznym rozwinięciem” (Klus-Stańska, 2010, s. 348). Obserwacje te badaczka poszerzyła w kolejnej publikacji pt. Paradygmaty dydaktyki. Myśleć teoria o praktyce (2018), w której klasyfikuje omawianą teorię w ramie paradygmatu obiektywistycznego (Klus-Stańska, 2018, s. 63-71). Jakkolwiek jest to słuszne określenie, to należy każdorazowo

14 Zwracam uwagę na datę publikacji w celu podkreślenia głębokiego opóźnienia dydaktyki ogólnej w porównaniu z procesem przywracania „nieobecnych dyskursów” przez inne dyscypliny pedagogiczne, co miało miejsce na przełomie lat 8o. i 9o. XX wieku. Dydaktyka ogólna ma tu nie tylko zadanie związane z krytycznym otwarciem się na współczesne nurty zachodnie, ale i przywrócenie zerwanej łączności pokoleniowej z przedstawicielami okresu II RP i czasów wcześniejszych. Warto odnotować, że przed Klus-Stańską, bo już w 1993 roku, Teresa Bauman opublikowała w zbiorowej redakcji tekst o tworzących się stereotypach w dydaktyce ogólnej. Nie zdecydowała się jednak na personalną krytykę osób odpowiedzialnych za „zastygły dogmat” dydaktyki, zarysowując jednak nową - emancypacyjną perspektywę rozwoju dyscypliny. Artykuł ten - prawdopodobnie niedoceniony w swoim czasie - wymaga dziś przypomnienia (patrz: Bauman, 1993). 
wyjaśniać, że to, co marksiści pojmowali jako obiektywistyczne, było przede wszystkim antypersonalistyczne ${ }^{15}$.

Kolejny głos porządkujący ramy teoretyczne dydaktyki, precyzyjnie pozycjonujący jej znaki i znaczenia, ze szczególnym uwzględnieniem paradygmatu humanistycznego, padł ze strony Anny Sajdak w obszernym dziele znanym pt. Paradygmaty kształcenia studentów i wspierania rozwoju nauczycieli akademickich (Sajdak, 2013). Wart odnotowania jest krytyczny wielogłos młodszego pokolenia badaczy, zebrany w dedykowanym współczesnej dydaktyce numerze Internetowego Magazynu Filozoficznego „Hybris”, pt. Filozofia, Dydaktyka, Polityka (Świrko-Pilipczuk i in., 2017).

Wyróżnieni autorzy podają niezbędne podstawy terminologiczne, porządkując grunt metodologiczny i semantyczny do otwarcia perspektyw badawczych i możliwości tworzenia nowej formacji intelektualnej w obszarze dydaktyki ogólnej. Jedną z takich perspektyw może być personalizm, umożliwiający rekonstrukcję osobowego i międzyosobowego wymiaru nauczania i uczenia się.

Kolejnych inspiracji należy szukać również poza dydaktyką, sięgając w pierwszej kolejności do dwoistości (Witkowski, 2013), którą - w mojej ocenie - traktować należy jako kategorię metaparadygmatyczną ${ }^{16}$. Myślenie w kategorii zdwajania „integralnie nastawionych” przeciwieństw, występujących w obrębie podmiotu, jak i między podmiotami ${ }^{17}$, jest niezbędne dla zrozumienia psychodynamizmów wewnątrz- i międzyosobowych, a w szczególności dynamizmu widzianego $\mathrm{w}$ dwoistości immanencji i transcendencji. Mowa bowiem o napięciach ontologiczno-epistemologiczno-aksjologicznych,

15 Przypominam, że usunięcie z pola widzenia pojęcia Osoby, było z jednej strony efektem przyjęcia kolektywistycznej definicji podmiotowości, a z drugiej faktem odrzucenia wielowiekowego dorobku humanistyki w dziedzinie ontologii i epistemologii oraz późniejszej dialogiki i fenomenologii.

W mojej ocenie „dwoistość” należy traktować nie jako nowy paradygmat, ale skłonność do granicznego sposobu myślenia, charakteryzującą myślicieli różnych epok i nurtów. Obraz takiej formacji pokazał Lech Witkowski, ilustrując między innymi sylwetki pedagogów polskich z lat 20. i 3o. XX wieku (por. Witkowski, 2013). Zastosowanie przeze mnie kategorii metaparadygmatyczności do oddania znaczenia dwoistości wynika $\mathrm{z}$ rozpoznania w niej niezbędnego kryterium myślenia o myśleniu ogólnie, a nie tylko określonego nurtu myślenia. Kryterium tym jest związek między myśleniem (cogito) i poznaniem (cogno$s c o$ ), a przede wszystkim doznawaniem owego poznania. Warto wiedzieć, że w najnowszej publikacji L. Witkowskiego pt. Psychodynamiki i ich struktury. Studia z humanistyki stosowanej (2020) autor proponuje pojęcie „ontodynamiki relacyjnej” oddające istotę sprzężonych dwoistości rozwojowych. Zgodnie z sugestią Witkowskiego publikację tę należy traktować jako ostatnią część tryptyku o dwoistości (Witkowski, 2013, 2015, 2020).

17 Bogusław Śliwerski, definiując dwoistość, zwraca uwagę na „jedność doznawania i działania”, „zapodmiotowioną w wymiarze tego, co jest między osobami specyficznie ludzkie” (Śliwerski, 2012, s. 192-193). 
generowanych podczas przejścia ze struktury biernego osobnika do aktywnej osoby. Napięcia te ilustrują semantyczną przestrzeń personalizmu, korzystającego przy tym z dorobku klasycznej ontologii i epistemologii oraz wspomnianych wcześniej dialogiki, hermeneutyki i fenomenologii.

Natomiast dzieło Karola Wojtyły pt. Osoba i czyn z 1969 roku (aktualne 3 wydanie, 2000) stanowi wzorcowy przykład tego podejścia, stając się bardzo aktualnym źródłem inspiracji dla wielu dyscyplin uwalniających się z jarzma marksizmu. Znajduje to swoje egzemplifikacje w takich publikacjach, jak: Podstawy psychologii realistycznej według Karola Wojtyly (Harciarek, 2008); Prawda jako zasada wychowania - podstawy pedagogii personalistycznej Karola Wojtyly (Starnawski, 2009); Podstawy pedagogiki otwartej (Nowak, 1999), wktórej autor akcentuje ontyczną strukturę człowieka w postaci „relacyjności bytu istniejącego w sobie”. Warto również przywołać najnowszą publikację stricte filozoficzną pt. Dynamizm człowieka w ujęciu Karola Wojtyły i Józefa Tischnera (Pala, 2019), przypominającą już we wprowadzeniu o tradycji hylemorficznego ujmowania struktury stawania się przez człowieka coraz bardziej ludzkim i międzyludzkim.

\section{Próba definiowania nowej koncepcji - modus Bycia nauczycielem}

W źródle koncepcji „egzystencjału personalnego” próba jego zdefiniowania prezentuje się następująco:

Egzystancjał personalny wyraża stopień uczestnictwa nauczyciela akademickiego we własnych wykładach. Użycie słowa „egzystancjał"18 wynika z potrzeby wyodrębnienia nauczania, jako sposobu bycia, od innych przejawów ludzkiej egzystencji. Sposób bycia właściwy nauczaniu definiuje przydawka „personalny" ${ }^{19}$. Wskazuje ona na aktywność własnego „ja" zarówno w sensie osobistym - (intra)personalnym, jak i międzyosobowym - (inter)personalnym. Dwoistość ta wynika z faktu, że w polu doświadczenia siebie przez nauczyciela zawsze znajduje się doświadczający siebie drugi człowiek.

Niezbędne minimum terminologiczne, jakim operować należy przy interpretacji powyższej definicji, można sprowadzić do dwóch pojęć: (1) „stawania się"

18 Przedrostek ex + rdzeń (s)istere, od złączenia których wywodzi się znamienne słowo „egzystencja”, sprowadziłem do formy egzystencjału, aby za pomocą gramatycznego niuansu wyodrębnić różnicę między znaczeniami obydwu wyrazów, a zarazem pozostawić ich podobieństwo rodzajowe. Egzystencjał jest rodzajem egzystencji, a więc istotowo ludzkiego sposobu bycia, z tą różnicą, że dotyczy on przejawów działania i dziania się człowieka nauczającego. Pojęcie „egzystencjału” występuje w znanym dziele Martina Heideggera Bycie i czas (2005, s. 184). Termin ten nie jest jednak tożsamym z proponowaną koncepcją, a jego zaistnienie nie miało związku z pracą Heideggera.

19 Docelowo, na końcu rozdziału rozprawy, definiuję trzy rodzaje egzystencjalów, wobec których nazwa „personalny” występuje w roli ogólnej ramy pojęciowej. 
(łac. fieri) oraz (2) „samostanowienia”. Są to kategorie nadrzędne, pytające kolejno o to, jakie są przejawy tego „ja”, które faktycznie jest „mną”, oraz co w istocie stanowi „o mnie” jako o osobie nauczyciela (wykładowcy)? W odpowiedzi na pierwszą część tak postawionego pytania ukazuje się problem autentyczności lub fałszywo ści uczestnictwa w nauczaniu. Stawanie się faktycznym nauczycielem oznacza zdolność do wyrażania krytycznego myślenia i sprzeciwu na rzecz przeżycia dobra wspólnego, zaś postawa fałszywa cechuje się konformizmem i unikiem na rzecz dobra własnego. Wraz z ujawnieniem lub skrywaniem autentycznego „ja” dają o sobie znać wspomniane już uczucia sympatii, empatii, pasji lub apatii. Wiąże się to bowiem ze stopniem nasilenia ujawnienia autentycznego "ja” przed innymi osobami, co może dla nich stanowić „impuls aktywujący” lub impuls degradujący ${ }^{20}$. Brak ujawnienia autentycznego "ja” u wykładowcy ogranicza "prawo do pełnego uczestnictwa” w wykładzie jego studentów. Prawo uczestnictwa w wykładzie jest wówczas złamane przez samego wykładowcę.

Stawanie się autentycznym „ja”, a więc tym „ja”, które faktycznie jest „mną", wymaga znajomości głębi własnej świadomości i wysiłku przechodzenia z jej „funkcji odzwierciedlającej” do funkcji refleksyjnej, a z refleksyjnej do reflektywnej. Pierwsza odpowiada za widzenie rzeczywistości taką, jaką jest, ilustrując jej ogląd. Druga, za widzenie pod różnym kątem i z różnych punktów patrzenia, kształtując określony pogląd. Trzecia, za przeżycie wglądu w samego siebie, na skutek doznania sprawczości i odpowiedzialności za ujawnienie własnego ,ja” i „drugiego ja”.

Egzystencjał odpowiada na pytania: co to znaczy „Być” wykładowcy i jak owo „bytowanie” się objawia. Nazwy trzech profili (ginetycznego, heurystycznego, dydaktycznego) wywodzą się z greckiej dystynkcji widocznej na pograniczu znaczeń czasowników ginōskō $\bar{o}^{21}$ (poznaję przez doznanie siebie), polegający na przeżyciu własnej podmiotowości (samodoświadczeniu siebie jako osoby), $\mathrm{w}$ akcie poznania nauczanego przedmiotu i uczestniczących w tym podmiotów; heuriskō (odnajduję, poszukując), oparty na toczeniu pogłębionej refleksji nad przedmiotem poznania - didáskō (nauczam instrumentalnie), kiedy akcent pada na poznanie poprzez przekazywanie informacji do wiadomości.

20 Określenie „impulsu aktywacyjnego” za: (Wojtyła, s. 453), natomiast określenie „impulsu degradującego" jest propozycją autorską. Podkreślam, że w obydwu przypadkach „impuls” rodzi się wewnątrz osoby.

21 Dokładna analiza etymologiczno-semantyczna przekracza rozmiary artykułu. Warto jednak podkreślić, że czasownik ginōskō ( $\gamma \iota v \omega ́ \sigma \kappa \omega)$, który pochodzi od hebrajskiego pojęcia yode'a עזי (od idei głębszego poznania i samodoświadczenia), stanowi nieuwzględniane dotąd w pedagogice znaczenie ludzkiego poznania, mogące pogłębić rozumienie podmiotowości nauczającej i uczącej się. 
Dla zobrazowania niektórych wybranych kategorii ${ }^{22}$, składających się na wielowymiarową strukturę koncepcji egzystencjałów personalnych, służy ich zbiorcze zilustrowanie w poniższej tabeli.

Tabela 2. Niektóre kategorie koncepcji egzystencjałów personalnych opisane $w$ artykule

\begin{tabular}{|c|c|c|c|c|}
\hline & & $\begin{array}{l}\text { Egzystencjał } \\
\text { ginetyczny }\end{array}$ & $\begin{array}{l}\text { Egzystencjał } \\
\text { heurystyczny }\end{array}$ & $\begin{array}{l}\text { Egzystencjał } \\
\text { dydaktyczny }\end{array}$ \\
\hline & Etymologia: & $\begin{array}{l}\text { gr. czasownik: } \\
\text { ginōskō }(\gamma \iota \nu \omega ́ \sigma \kappa \omega)\end{array}$ & 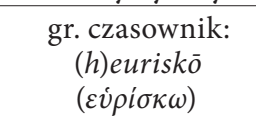 & $\begin{array}{c}\text { gr. czasownik: } \\
\text { didáskōo }(\delta \iota \delta \alpha \dot{\alpha} \sigma \kappa \omega)\end{array}$ \\
\hline 1. & $\begin{array}{l}\text { Poziom uczestnictwa } \\
\text { we własnym wykła- } \\
\text { dzie }\end{array}$ & Maksymalistyczny & Zaawansowany & Minimalistyczny \\
\hline 2. & $\begin{array}{l}\text { Tożsamość wykła- } \\
\text { dowcy }\end{array}$ & Sprawca czynu & Twórca dzieła & $\begin{array}{l}\text { Wykonawca czyn- } \\
\text { ności }\end{array}$ \\
\hline 3. & $\begin{array}{l}\text { Aktualizowana funk- } \\
\text { cja świadomości }\end{array}$ & Reflektywna & Refleksyjna & Odzwierciedlająca \\
\hline 4. & Efekt poznawczy & $\begin{array}{l}\text { Wgląd wewnątrz- } \\
\text { i międzyosobowy }\end{array}$ & $\begin{array}{l}\text { Pogląd przedmio- } \\
\text { towo-podmiotowy }\end{array}$ & Ogląd przedmiotu \\
\hline 5. & $\begin{array}{l}\text { Struktura kontaktu } \\
\text { między wykładowcą } \\
\text { a studentem }\end{array}$ & $\begin{array}{l}\text { Osobista korelacja: } \\
\text {,ja - drugie ja” }\end{array}$ & $\begin{array}{l}\text { Partnerska relacja: } \\
\text { ja - ty (wy) }\end{array}$ & $\begin{array}{l}\text { Formalne ustosun- } \\
\text { kowanie: ja - oni }\end{array}$ \\
\hline 6. & $\begin{array}{l}\text { Warunki nawiązania } \\
\text { kontaktu }\end{array}$ & Napotkanie & Spotkanie & Zebranie \\
\hline 7. & $\begin{array}{l}\text { Zasięg nawiązanego } \\
\text { kontaktu }\end{array}$ & $\begin{array}{l}\text { Uczestnictwo } \\
\text { w przeżyciu unie- } \\
\text { sienia i olśnienia }\end{array}$ & $\begin{array}{l}\text { Udział w dyskursie } \\
\text { społecznym }\end{array}$ & $\begin{array}{l}\text { Przekazywanie } \\
\text { wiedzy do wiado- } \\
\text { mości }\end{array}$ \\
\hline 8. & $\begin{array}{l}\text { Graniczne doświad- } \\
\text { czenia psycho-emo- } \\
\text { tywne }\end{array}$ & $\begin{array}{l}\text { Przeżycie interde- } \\
\text { pendencji i trans- } \\
\text { dependencji }\end{array}$ & $\begin{array}{l}\text { Doświadczenie } \\
\text { pogłębionej relacji } \\
\text { interpersonalnej }\end{array}$ & $\begin{array}{l}\text { Doznanie wyosob- } \\
\text { nienia (alienacji) }\end{array}$ \\
\hline 9. & $\begin{array}{l}\text { Recepcja siebie i siebie } \\
\text { wzajemnie podczas } \\
\text { kontaktu }\end{array}$ & Bycie „Kimś” & Bycie „jakimś” & Bycie „czymś” \\
\hline 10. & $\begin{array}{l}\text { Doznania między- } \\
\text { i wewnątrzpodmio- } \\
\text { towe }\end{array}$ & Empatia, sympatia & Pasja & Apatia \\
\hline
\end{tabular}

Źródło: opracowanie własne

\section{Dyskusja koncepcji na tle innych badań}

Z przeprowadzonych analiz wynika, że wiele zjawisk intra- i interpersonalnych w nauczaniu odbywa się pod niewidzialną warstwą wykładu. W historii polskiej pedagogiki i dydaktyki ogólnej znalazłem dwie wzmianki o powin-

22 Artykuł nie uwzględnia analiz sensotwórczych aktów mowy, wskazujących na identyfikacje stylistyczne i semantyczne, stosowane przez reprezentantów poszczególnych profili egzystencjalnych (por. Paluch, 2020, s. 298-307) 
ności podjęcia tak pogłębionych analiz nauczania. Pierwszą przypisać można Stefanowi Baleyowi, który już przed wojną pisał: „Można to nazwać zasadą głębi, gdyż poruszenie sfery emocjonalnej razem z intelektualną jest objawem dotarcia bodźców do głębszych warstw psychiki” (Baley, 1960, s. 182). W innym miejscu, myśląc o nauczycielach, dodał: „[...] nasuwałaby się potrzeba indagowania ich nie tylko o różne właściwości, które oni posiadają, lecz także o przeżycia, których doznają w związku z pracą wychowawczą (podkr. moje - M.P.). A zatem byłyby to $\mathrm{z}$ jednej strony te przeżycia, które towarzyszą bezpośredniemu wychowawczemu kontaktowi $\mathrm{z}$ wychowankami, jak i te, których doznają, myśląc o sprawach wychowawczych (podkr. moje - M.P.)" (s. 239). Drugą wzmianką, choć dotyczącą jedynie studentów obecnych na wykładzie, była uwaga poczyniona przez Wincentego Okonia w sprawie „myśli własnych” podczas wykładu, wyrażonych w „dialogu wewnętrznym”, w „podskórnym toku wykładu”, będącym „nurtem przewodnim wykładu problemowego" (Okoń, 1971, s. 192-198). Można dziś przypuszczać, że Okoń podjąłby się takich badań, gdyby nie konieczność pozostawania wiernym wobec ideologii socjalistycznej.

Wyprowadzona $\mathrm{z}$ personalizmu kategoria świadomości refleksyjnej i reflektywnej może kojarzyć się z refleksyjną praktyką w teorii Donalda Schöna. Należy jednak podkreślić, że refleksyjność w ujęciu wymienionego autora wyprowadzona została $\mathrm{z}$ ramy progresywizmu. Nie przekreśla to jednak możliwości przeprowadzenia studium porównawczego między dwoma stanowiskami. Rozpoznane w badaniach kategorie granicznych przeżyć podczas nauczania (inter- i transdependencja) mogłyby przyczynić się do kolejnego studium porównawczego, między proponowaną koncepcją egzystencjałów personalnych a uznanymi pracami psychologicznymi, jak: teoria przepływu (Flow) Mihalego Csikszentmihalyiego, czy teorii samoskuteczności (Self-efficiency) Alberta Bandury. Poszukiwanie punktów stycznych i różnic można by przeprowadzić również między koncepcją egzystencjałów a psychologią integralną Kena Wilbera, osadzoną w nurcie psychologii transpersonalnej. Warto również zastanowić się, czy odkryte w badaniach przeżycia wykładowców i ich przejawy dają się wytłumaczyć w tradycyjnych kategoriach modelu dramaturgicznego Ervinga Goffmana, czy też elementami filozofii dialogu i agatologii Józefa Tischnera. Zasadne dla pogłębienia koncepcji podmiotu doznającego może być również wykorzystanie analiz Jacka Filka, dokonanych w ramach rozważań nad fenomenologią wychowania i projektem „Nowego Myślenia” oraz autorskiej koncepcji Andrzeja Nowickiego, znanej pod nazwą „inkontrologii”. 


\section{Podsumowanie - konieczne nowe odczytanie, dekonstrukcje i rekonstrukcje}

Otwarcie dydaktyki ogólnej na nowe nurty interpretacyjne i metodologiczne wymaga dekonstrukcji znaków i znaczeń narzuconych siłą „sowieckiej ofensywy ideologicznej”, jej „miękkiego transferu” do czasów nam współczesnych oraz bezkrytycznego przyjęcia myśli i nomenklatury anglosaskiej. W pierwszym wypadku wiąże się to $\mathrm{z}$ koniecznością i powinnością definitywnego rozliczenia się z twórczością Wincentego Okonia i rzesz jego naśladowców, z intencją - jak pisała Teresa Hejnicka-Bezwińska -

tworzenia warunków do lepszego rozumienia związków czasu teraźniejszego z czasem minionym, aby bardziej racjonalnym uczynić twórczy wysiłek podmiotów zainteresowanych konstruowaniem świata przyszłego, w którym edukacja będzie pełniła ważniejszą rolę [...], niż pełniła i pełni w świecie nam znanym (Hejnicka-Bezwińska, 2015, s. 23).

Tym samym oznacza to przywrócenie znaków i znaczeń usuniętych lub zdeformowanych przez obecny i miniony ustrój, w myśl rekonstrukcji wielowiekowej tradycji i dziedzictwa humanistycznego, przeniesionego "nad”, a zarazem "przez” marksizm odwagą i wysiłkiem intelektualnym Karola Wojtyły. Równocześnie proponowana koncepcja egzystencjałów personalnych otwarta jest na nurty i perspektywy o innej metodologicznej proweniencji, zwiększając szansę na krytyczne, ale i poddające się krytyce, zaistnienie we współczesnej nauce.

\section{BIBLIOGRAFIA}

Aebli, H. (1982). Dydaktyka psychologiczna. Zastosowanie psychologii Piageta do dydaktyki. Przeł. C. Kupisiewicz. Warszawa: PWN.

Baley, S. (1960). Psychologia wychowawcza w zarysie. Wyd. 5. Warszawa: Państwowe Wydawnictwo Naukowe.

Bauman, T. (1993). Przełamywanie stereotypów w myśleniu o procesie kształcenia. W: E. Rodziewicz, M. Szczepska-Pustkowska (red.), Od Pedagogiki ku Pedagogii (s. 38-51). Wydawnictwo „Edytor”.

Bereźnicki, F. (2015). Dydaktyka szkolna dla kandydatów na nauczycieli. Kraków: Oficyna Wydawnicza Impuls.

Chałasiński, J. (1968). Kultura i naród. Warszawa: Książka i Wiedza.

Dąbrowski, Z. (1975). Poznanie i działanie. Warszawa: Wydawnictwa Szkolne i Pedagogiczne.

Denzin, N.K., Lincoln, Y.S. (2014). Metody badań jakościowych. T. 1. Warszawa: PWN.

Graniewski, H., Kempista, M. (1963). Cybernetyka z lotu ptaka. Warszawa: Książka i Wiedza.

Harciarek, M. (2008). Podstawy psychologii realistycznej według Karola Wojtyly. Dom Wydawniczo-Księgarski KOS.

Hejnicka-Bezwińska, T. (2015). Praktyka edukacyjna w warunkach zmiany kulturowej. Warszawa: Wydawnictwo Naukowe PWN. 
Jakobson, R. (1960). Closing statement: Linguistics and poetics. W: T. Sebeok (red.), Style in language (s. 350-377). Cambridge, MA: M.I.T. Press.

Jemielniak, D. (2012). Badania jakościowe. Podejścia i teorie. T. I. Warszawa: PWN.

Klus-Stańska, D. (2010). Dydaktyka wobec chaosu pojęć i zdarzeń. Warszawa: Wydawnictwo Akademickie Żak.

Klus-Stańska, D. (2018). Paradygmaty dydaktyki. Myśleć teoriq o praktyce. Warszawa: Wydawnictwo Naukowe PWN.

Kozielecki, J. (1969). Rozwiązywanie problemów. Warszawa: PZWS.

Kozielecki, J. (1975). Psychologiczna teoria decyzji. Warszawa: PWN.

Krasiński, A. (2001). Teoria kształcenia wielostronnego Wincentego Okonia w dydaktyce szkolnej i katechetycznej. Seminare. Poszukiwania naukowo-pastoralne, 17, 89-98.

Kron, F.W. (2012). Pedagogika. Kluczowe zagadnienia. Podręcznik akademicki. Gdańsk: Gdańskie Wydawnictwo Psychologiczne.

Kupisiewicz, C. (1973). Podstawy dydaktyki ogólnej. Warszawa: PWN.

Kvale, S. (2012). Prowadzenie wywiadów. Warszawa: Wydawnictwo Naukowe PWN.

Lasswell, H. (1948). The Structure and Function of Communication in Society. W: L. Bryson (red.), The Communication of Ideas. New York: Harper \& Bros, Institute for Religious and Social Studies.

Lewicki, A. (1960). Procesy poznawcze i orientacja w otoczeniu. Warszawa: PWN.

Linhart, J. (1972). Proces i struktura uczenia się ludzi. Warszawa: Państwowe Wydawnictwo Naukowe.

Łuszczak, G. (2012). Od teorii stopni formalnych do teorii komunikacji i dialogu w dydaktyce szkolnej $i$ katechetycznej. Kraków: Wydawnictwo WAM.

Mayer, G. (1969). Cybernetyka a proces nauczania. Warszawa: PZWS.

Nowak, M. (1999). Podstawy pedagogiki otwartej. Lublin: RW KUL.

Okoń, W. (1967). Podstawy wykształcenia ogólnego. Warszawa: Nasza Księgarnia.

Okoń, W. (1971). Elementy dydaktyki szkoły wyższej. Warszawa: Państwowe Wydawnictwo Naukowe.

Okoń, W. (1987). Wprowadzenie do dydaktyki ogólnej. Warszawa: Wydawnictwo Naukowe PWN.

Okoń, W. (1991). Rzecz o edukacji nauczycieli. Warszawa: Wydawnictwa Szkolne i Pedagogiczne.

Okoń, W. (2003). Wprowadzenie do dydaktyki ogólnej. Wyd. 5. Warszawa: Wydawnictwo Akademickie Żak.

Ostrowska, U. (2005). Proces kształcenia. W: T. Pilch (red.), Encyklopedia pedagogiczna. T. 4. Warszawa: Wydawnictwo Akademickie Żak.

Pala, A. (2019). Dynamizm człowieka w ujęciu filozoficznym Karola Wojtyły i Józefa Tischnera. Kraków: Wydawnictwo Naukowe UP JPII.

Paluch, M. (2016a). Miary-godności pedagogów a wiary-godność dyscypliny. Granice (nie)przekraczalne. W: D. Urbaniak-Zając, J. Piekarski (red.), Wiarygodność akademicka w edukacyjnych praktykach. Łódź: Wydawnictwo Uniwersytetu Łódzkiego.

Paluch, M. (2016b). Wielostronne manipulacje twórcy wielostronnej teorii kształcenia. W: M. Wiśniewska (red.), Edukacja w PRL. Warszawa: Wydawnictwo Uniwersytetu Kardynała Stefana Wyszyńskiego.

Paluch, M. (2020). Dwoistość relacji dydaktycznej nauczyciel-dorosły uczeń [Rozprawa doktorska pod kierunkiem naukowym Prof. dr hab. Bogusława Śliwerskiego]. Akademia Pedagogiki Specjalnej im. Marii Grzegorzewskiej w Warszawie [maszynopis niepublikowany].

Poletajew, A. (1961). Zagadnienia cybernetyki. Państwowe Wydawnictwo Techniczne.

Reykowski, J. (1958). Introspekcja a teoria odbicia. W: Z problematyki psychologii i teorii poznania. Warszawa: PWN. 
Rubinsztejn, S.L. (1962). Podstawy psychologii ogólnej. Warszawa: Spółdzielnia Wydawniczo-Handlowa Książka i Wiedza.

Sajdak, A. (2013). Paradygmaty kształcenia studentów i wspierania rozwoju nauczycieli akademickich. Teoretyczne podstawy dydaktyki akademickiej. Kraków: Oficyna Wydawnicza Impuls.

Shannon, C.E. (1948). A Mathematical Theory of Communication. Bell System Technical Journal, 27 (July and October), 379-423, 623-656.

Shannon, C.E., Weaver, W. (1949). The Mathematical Theory of Communication. Urbana: University of Illinois Press.

Starnawski, W. (2009). Prawda jako zasada wychowania. Warszawa: Wydawnictwo Uniwersytetu Kardynała Stefana Wyszyńskiego.

Śliwerski, B. (2012). Pedagogika ogólna. Podstawowe prawidłowości. Wyd. 2. Kraków: Oficyna Wydawnicza Impuls.

Świrko-Pilipczuk, J., Moroz, J., Szwabowski, O. (2017). Filozofia, Dydaktyka, Polityka. Hybris. Internetowy Magazyn Filozoficzny, 1.

Tałyzina, N.F. (1980). Kierowanie procesem przyswajania wiedzy. Warszawa: Wydawnictwa Szkolne i Pedagogiczne.

Tomaszewski, T. (1969). Wstęp do psychologii. Wyd. 3. Warszawa: Państwowe Wydawnictwo Naukowe.

Tomaszewski, T. (1970). Z pogranicza psychologii i pedagogiki. Państwowe Zakłady Wydawnictw Szkolnych.

Witkowski, L. (2013). Przełom dwoistości w pedagogice polskiej. Kraków: Oficyna Wydawnicza Impuls.

Witkowski, L. (2015). VERSUS. O dwoistości strukturalnej faz rozwoju w ekologii cyklu życia psychodynamicznego modelu Erika H. Eriksona. Dąbrowa Górnicza: WSB w Dąbrowie Górniczej.

Witkowski, L. (2020). Psychodynamiki i ich struktury. Studia z humanistyki stosowanej. Toruń: Wydawnictwo Adam Marszałek.

Wojtyła, K. (2000). Osoba i czyn oraz inne studia antropologiczne. Wyd. 3. Lublin: Towarzystwo Naukowe KUL.

Zaczyński, W. (1984). Teoria wielostronnego kształcenia jako paradygmat współczesnej dydaktyki - rozważania wstępne. Kwartalnik Pedagogiczny, 2.

Zaczyński, W. (1990). Uczenie sie przez przeżywanie. Warszawa: WSiP.

\section{SUMMARY}

\section{Personal existentiality \\ - towards the new concept in General Didactic}

The article indicates the possibility of using the basic term of philosophical anthropology, which is the Person (person-creating), in order to get out of the impersonal Marxist-Leninist epistemology burdening Polish general didactics. In order to make this procedure readable, the author undertook a critical look at the scientific work of Wincenty Okon (1914-2011), who was considered an undisputed authority in the history of Polish post-war didactics. This criticism takes place against the background of the emerging essence of Man, illustrated by Karol Wojtyla (1920-2005), in the work known as Person and Act (1969). Thus, the article abounds in philosophical language and the neologisms resulting from it, which have not been used for a long time in the Polish discourse of teaching and learning theory. Such author's concepts include "personal existence", emphasizing the need to separate teaching as a way of Being, from other manifestations of human existence. On this basis, the existential profiles of academic lecturers were shown, derived theoretically from personalism. 
Three personal existences have been distinguished, which are an interpretation of the levels of teacher participation in his own lecture: (1) didactic (greek: didáskō, I teach); (2) heuristic (heuriskō, I seek - I find); (3) ginetic (ginōskō, I know through experience), consisting in experiencing my own subjectivity (self-experience of myself as a person), in the act of getting to know the taught subject and entities involved. Each of the three existences has a specific type of identity: (1) the passive performer of the activity, (2) the active creator of the work, and (3) the perpetrator of the teaching act experiencing a relationship with himself and others. The article has a propaedeutic nature. A full description of selected features and indicators of each profile and their in-depth theoretical and methodological assumptions constitute the main content of the doctoral dissertation and a separate publication prepared on its basis

KEYWORDS: experiencing, teaching, subjectivity, participation, Person, marxism, personalism 